\title{
Janthinobacterium agaricidamnosum sp. nov., a soft rot pathogen of Agaricus bisporus
}

\author{
Steven P. Lincoln, ${ }^{1}$ Terence R. Fermor ${ }^{1}$ and B. J. Tindall ${ }^{2}$
}

1 Horticulture Research

International,

Wellesbourne,

Warwickshire, UK

2 DSMZ - Deutsche

Sammlung von

Mikroorganismen und

Zellkulturen $\mathrm{GmbH}$,

Braunschweig, Germany

Author for correspondence: Steven P. Lincoln. Tel: +44 1789 470382. Fax: +44 1789470552. e-mail: steve.lincoln@hri.ac.uk

\begin{abstract}
A novel bacterium has been found that causes a soft rot disease of Agaricus bisporus, the cultivated mushroom. It has been characterized using nutritional, physiological, chemical and molecular techniques. Based on these data, it was shown to have many characteristics in common with members of the genus Janthinobacterium. Despite similarities to the only described species within this genus, Janthinobacterium lividum, there were a number of differences between the mushroom pathogen isolated and this species. Despite the high degree of genotypic similarity between members of the genus Janthinobacterium and Herbaspirillum, as evidenced by DNA-RNA hybridization, and the high degree of 165 rDNA sequence similarity between members of the genera Janthinobacterium, Herbaspirillum, Oxalobacter and Duganella, as well as the generically misnamed Pseudomonas lemoignei, it was possible to show that members of the genus Janthinobacterium could be easily distinguished from these taxa. The data also indicated that the mushroom pathogenic strains represent a novel species within the genus Janthinobacterium for which the name Janthinobacterium agaricidamnosum sp. nov. is proposed. The type strain of this species has been deposited in the Deutsche Sammlung von Mikroorganismen und Zellkulturen GmbH, Braunschweig, Germany, as DSM $9628^{\top}$ and at the National Collection of Plantpathogenic bacteria, UK, as NCPPB 3945'. To aid practical control of the disease, the effect of the relative humidity on symptom expression on Agaricus bisporus was determined.
\end{abstract}

Keywords: Janthinobacterium agaricidamnosum, Agaricus bisporus pathogen, taxonomy, 16S rDNA sequence, chemotaxonomy

\section{INTRODUCTION}

A soft rot disease has caused localized devastation of a crop of Agaricus bisporus (Sinden Hauser 3.8), a brown strain of the cultivated mushroom, on a farm in southern England. Some mushrooms dissolved completely in situ within $2 \mathrm{~d}$ of symptoms becoming apparent. Other, less dramatic, symptoms included pitting and sticky blotches on the mushroom cap surface. Disease outbreaks showing similar symptoms, have been reported from cave farms in France and with increasing frequency from British mushroom farms.

\section{Abbreviation: $\mathrm{RH}$, relative humidity.}

The EMBL accession number for the 16S rDNA sequence of Janthinobacterium agaricidamnosum sp. nov. is Y08845.
The symptoms are similar to those of rapid rot of Agaricus bitorquis, grown at a higher temperature $\left(28^{\circ} \mathrm{C}\right)$, which is caused by Burkholderia gladioli pv. agaricicola (Lincoln et al., 1991). The causal organism of the new $A$. bisporus disease has been isolated and characterized using a combination of phenotypic (standard biochemical and nutritional bacteriological tests in harness with chemical profiling) and genotypic $(\mathrm{G}+\mathrm{C}$ base composition of total genomic DNA, DNA-DNA hybridization and 16S rDNA sequence analysis) techniques. A high degree of similarity was established between members of the genera Janthinobacterium, Oxalobacter, Duganella and Herbaspirillum, together with the generically misnamed species Pseudomonas lemoignei, as evidenced by DNA-RNA hybridization studies and 16S rDNA sequence analysis. On the basis of this information, it was necessary to consider, together with phenotypic 
data, whether the genus Janthinobacterium should be expanded to include those members of the genera listed above. The use of whole-cell fatty acid analysis was found particularly useful for distinguishing members of the genus Janthinobacterium from other, closely related genera. The mushroom pathogenic strains could be shown to be members of the genus Janthinobacterium based on 16S rDNA sequence and fatty acid analysis. However, DNA-DNA hybridization and comparative biochemical studies of these isolates and members of the species Janthinobacterium lividum indicated that the mushroom pathogens constitute a novel species within the genus Janthinobacterium. In the light of these findings, it was considered appropriate to emend the description of the genus Janthinobacterium.

On the basis of the taxonomic study, further studies on the pathogenicity of the members of the genus Janthinobacterium were undertaken. A small mushroom crop was grown to investigate environmental effects on symptom expression and to check anecdotal evidence that brown Agaricus strains were more susceptible to the pathogen than white strains. The bacterial diseases normally associated with mushrooms are brown blotch, caused by Pseudomonas tolaasii (Paine, 1919); ginger blotch, caused by 'Pseudomonas gingeri' (Wong et al., 1982), and drippy gill, caused by Pseudomonas agarici (Young, 1970). This is the first bacterial disease of $A$. bisporus to be caused by a species of the genus Janthinobacterium. Other species causing bacterial diseases of mushrooms which are not members of the genus Pseudomonas are $B$. gladioli pv. agaricicola (Lincoln et al., 1991) and Ewingella americana (internal stipe necrosis) (Inglis et al., 1996).

\section{METHODS}

Bacterial cultures. Species and strains of bacteria compared in this study are listed in Table 1.

Samples of diseased mushroom tissue were transferred aseptically to sterile quarter-strength Ringer's solution and a ten-fold dilution series was inoculated onto Pseudomonas agar F (PAF; Merck) and nutrient agar (Oxoid) and incubated at $25{ }^{\circ} \mathrm{C}$ for $24 \mathrm{~h}$. Single colonies were isolated from the dilution plates using a sterile wire and streaked onto plates of the appropriate agar and cultured at $25^{\circ} \mathrm{C}$. Each isolate was ' white line tested' for identity as $P$. tolaasii (Wong \& Preece, 1979), tested on mushroom tissue blocks as an initial pathogenicity test (Gandy, 1968) and plated onto Pseudomonas isolation agar (PIA; Difco). Two isolates produced severe symptoms; these were designated $\mathrm{W} 1 \mathrm{r} 3^{\mathrm{T}}$ $\left(=\mathrm{NCPPB} 3945^{\mathrm{T}}=\mathrm{DSM} 9628^{\mathrm{T}}\right)$ and C1b4 (= NCPPB 3965) and were from different mushroom houses on the same farm. $\mathrm{W} 1 \mathrm{r} 3^{\mathrm{T}}$ was from a rotting mushroom and $\mathrm{C} 1 \mathrm{~b} 4$ was from a blotched mushroom. Both of these isolates were applied to growing mushrooms at Horticulture Research International to check pathogenicity. Soft rot bacterium H5 (= NCPPB 3964) was isolated from $A$. bisporus on a commercial mushroom farm in France and was a gift from J. M. Olivier, INRA Bordeaux. Difficulty was experienced in maintaining cultures of the mushroom pathogens on agar as the cultures died if left for more than $10 \mathrm{~d}$ without subculturing. The isolates were stored freeze-dried and in liquid nitrogen. Working cultures were subcultured weekly.

Characterization and identification of the causal organism. Test organisms were subjected to a number of biochemical tests (Gerhardt et al., 1981; Lelliott \& Stead, 1987). All strains were subjected to biochemical testing in the API $20 \mathrm{NE}$, API 50CH and the BIOLOG GN microtitre plate systems. All strains were pre-cultivated on nutrient agar for $24 \mathrm{~h}$ at $28^{\circ} \mathrm{C}$ and resuspended in the appropriate test media according to the manufacturer's instructions.

Chemical characterization. All strains of the genera Janthinobacterium and Herbaspirillum used in the present chemotaxonomic study were grown in nutrient broth at $28^{\circ} \mathrm{C}$ for 24 h, shaken at 100 r.p.m. on an orbital shaker. Cells were harvested by centrifugation at 10000 r.p.m. for $20 \mathrm{~min}$. Cell pellets were freeze-dried and the dried material was stored at $-20^{\circ} \mathrm{C}$ until used for the analyses.

Whole-cell fatty acid analysis (Moss et al., 1980) of the new pathogenic isolates was performed at MAFF Central Science Laboratory (CSL), Harpenden, UK, as in Lincoln et al. (1991), and at the DSMZ Braunschweig, Germany (all strains), where methods were employed which allowed selective hydrolysis of ester- and amide-linked fatty acids (B. J. Tindall, unpublished results).

Extraction and analysis of respiratory lipoquinones and polar lipids. Respiratory lipoquinones and polar lipids were extracted from $100 \mathrm{mg}$ freeze-dried material using the twostage method described by Tindall $(1990 \mathrm{a}, \mathrm{b})$.

Respiratory lipoquinones were separated into their different classes (menaquinones and ubiquinones) by TLC; UVabsorbing bands, corresponding to menaquinones or ubiquinones, were removed from the plate and analysed further by HPLC as described by Tindall (1990a, b).

Polar lipids were separated by two-dimensional silica gel TLC (Macherey-Nagel) as described by Tindall (1990a, b). Total lipid material was detected using dodecamolybdophosphoric acid and specific functional groups were detected using Zinzadze reagent (phosphate), ninhydrin (free amino groups), periodate-Schiff $(\alpha$-glycols), Dragendorff (quaternary nitrogen), anisaldehyde-sulphuric acid (glycolipids) and $\alpha$-naphthol-sulphuric acid (glycolipids).

Resistance to antibiotics. Antibiotic resistance of the mushroom pathogenic strains and the J. lividum strains was tested on plates of Iso-sensitest agar (Oxoid) pre-inoculated with the test organism and dried. Antimicrobial susceptibility test discs (Oxoid) were placed on the agar surface. These included penicillin $\mathrm{G}(10 \mu \mathrm{g}$ disc $)$, vancomycin $(30 \mu \mathrm{g}$ disc), erythromycin $(15 \mu \mathrm{g}$ disc), streptomycin $(10 \mu \mathrm{g}$ disc), tetracycline ( $30 \mu \mathrm{g}$ disc) and nalidixic acid ( $30 \mu \mathrm{g}$ disc). The plates were then incubated at $25^{\circ} \mathrm{C}$ for $48 \mathrm{~h}$. If the area surrounding a disc was free from bacterial growth, it was recorded that the organism was sensitive to that antibiotic.

DNA extraction and PCR amplification of the 16S rDNA. Genomic DNA extraction, PCR-mediated amplification of the 16S rDNA and purification of PCR products was carried out as described previously (Rainey \& Stackebrandt, 1993; Rainey et al., 1992a). Purified PCR products were sequenced using the Taq DyeDeoxy Terminator Cycle Sequencing kit (Applied Biosystems) as directed in the manufacturer's protocol. Sequence reactions were electrophoresed using the Applied Biosystems 373A DNA Sequencer. The 16S rDNA sequences were aligned manually. The global phylogenetic position of strain $\mathrm{W} 1 \mathrm{r} 3^{\mathrm{T}}$ was investigated using the ARB database (Ludwig \& Strunk, 1996). On the basis of this 
Janthinobacterium agaricidamnosum sp. nov.

Table 1. Species and strains of bacteria compared in this study

\begin{tabular}{|c|c|c|c|}
\hline Name & Culture collection no.* & $\begin{array}{l}\text { No. used in this } \\
\text { study }\end{array}$ & Source \\
\hline Janthinobacterium agaricidamnosum & NCPPB $3945^{\mathrm{T}}\left(=\mathrm{DSM} 9628^{\mathrm{T}}\right)$ & $\mathrm{W} 1 \mathrm{r} 3^{\mathrm{T}}$ & Rotting $A$. bisporus, UK \\
\hline Janthinobacterium agaricidamnosum & NCPPB 3965 & $\mathrm{C} 1 \mathrm{~b} 4$ & Blotches $A$. bisporus, UK \\
\hline Janthinobacterium agaricidamnosum & NCPPB 3964 & $\mathrm{H} 5 \dagger$ & $\begin{array}{l}\text { Rotting } A . \text { bisporus, } \\
\text { France }\end{array}$ \\
\hline Janthinobacterium lividum & NCIMB 9230 & & Soil, UK \\
\hline Janthinobacterium lividum & NCIMB 9414 & & Spring water, UK \\
\hline Janthinobacterium lividum & DSM $1522^{T}$ & & Soil, USA \\
\hline Herbaspirillum seropedicae & DSM $6445^{\mathrm{T}}$ & & Oryza sativa roots, Brazil \\
\hline Herbaspirillum rubrisubalbicans & DSM $9940^{\mathrm{T}}$ & & $\begin{array}{l}\text { Saccharum officinarum, } \\
\text { USA }\end{array}$ \\
\hline Herbaspirillum $\mathrm{sp}$. & DSM 11581 (= LMG 2285) & & $\begin{array}{l}\text { Saccharum officinarum, } \\
\text { Australia }\end{array}$ \\
\hline Herbaspirillum $\mathrm{sp}$. & DSM $11582(=$ LMG 5321) & & Leg wound, Sweden \\
\hline Herbaspirillum sp. & DSM $11580(=$ LMG 5523) & & Contaminant, Sweden \\
\hline
\end{tabular}

* NCPPB, National Collection of Plant-pathogenic Bacteria, Central Science Laboratory, York, UK; DSM, Deutsche Sammlung von Mikroorganismen und Zellkulturen, Braunschweig, Germany; NCIMB, National Collection of Industrial and Marine Bacteria, Aberdeen, UK; LMG, Collection of Bacteria of the Laboratorium voor Microbiologie, K.-L. Ledenganckstraat, Gent, Belgium. T, Type strain.

$\dagger$ Gift from J. M. Olivier, INRA, Bordeaux, France.

work, the $16 \mathrm{~S}$ rDNA sequences were compared with the existing 16S rDNA database for members of the phyletic group defined as the $\beta$-subclass of the Proteobacteria. A greater degree of resolution among closely related taxa was performed using the ae2 editor (Maidak et al., 1997). Similarity values were calculated based on the aligned $16 \mathrm{~S}$ rDNA sequences from the following organisms: J. lividum DSM 1522 (Y08846); Telluria mixta (X65589); Telluria chitinolytica (X65590); Duganella zoogloeoides IAM 12670 (D14256); Oxalobacter formigenes strain $\mathrm{OXB}^{\mathrm{T}}$ (U49757); $P$. lemoignei $\mathrm{LMG} 2207^{\mathrm{T}}$ (X92555); Herbaspirillum seropedicae DSM $6445^{\mathrm{T}}$ (Y10146). Strain designations for $T$. mixta and $T$. chitinolytica were not given in the EMBL database, although in the work of Bowman et al. (1993), in which these sequences were determined, only $T$. mixta ACM $1762^{\mathrm{T}}\left(=\mathrm{ATCC} 49108^{\mathrm{T}}\right)$ and $T$. chitinolytica $20 \mathrm{M}^{\mathrm{T}}(=\mathrm{ACM}$ $3522^{\mathrm{T}}=$ CNCM I-804 ${ }^{\mathrm{T}}$ ) were used.

DNA base composition. The percentage $\mathrm{G}+\mathrm{C}$ content in the DNA was estimated using a DNA mid-thermal melting point method (Marmur \& Doty, 1962). DNA was extracted from the bacteria using the method of Neumann et al. (1992).

DNA-DNA hybridization. DNA was isolated by passing the cell suspensions through a French press and purified on a hydroxyapatite column according to the method of Cashion et al. (1977). Prior to hybridization, the $\mathrm{G}+\mathrm{C}$ base content of the two Janthinobacterium strains was assessed by hydrolysis of the purified DNA with P1 nuclease and dephosphorylation with bovine alkaline phosphatase (Mesbah et al., 1989). Deoxyribonucleosides were analysed by HPLC (LKB) on a Nucleosil 100-5 C18 $(250 \times 4 \mathrm{~mm})$ column fitted with a guard column $(20 \times 4 \mathrm{~mm})$ of the same material using the conditions described by Tamaoka \& Komagata (1984). DNA-DNA hybridization was carried out according to the method of De Ley et al. (1970), with modifications, using a Gilford System 2600 spectro- photometer equipped with a Gilford 2527-R thermoprogrammer and plotter. The DNA concentration was $45 \mu \mathrm{g} \mathrm{ml}^{-1}$. Due to the high $\mathrm{G}+\mathrm{C}$ content of the DNA, $20 \%$ DMSO was added to $2.5 \times$ SSC buffer to depress the DNA melting point $\left(T_{\mathrm{m}}\right)$ (Escara \& Hutton, 1980). The resulting buffer was $2 \times \mathrm{SSC}+20 \%$ DMSO. The mean $T_{\mathrm{m}}$ was determined from the DNA melting curves and the optimal temperature of renaturation (TOR) was calculated according to the equation $\mathrm{TOR}=T_{\mathrm{m}}-25$.

The DNA-DNA hybridization values were calculated by regression analysis of the renaturation rates over the time period 10-30 min after starting the reaction using the computer program TRANSFER.BAS (Jahnke, 1992).

Host tests. The relative susceptibility of white and brown strains of $A$. bisporus to the soft rot disease was determined in crops grown using standard commercial procedures in two mushroom-growing rooms. Mushrooms were grown in pots $(25 \mathrm{~cm}$ diameter $)$ containing $2.5 \mathrm{~kg}$ fresh weight compost in a random block design. The eight treatments consisted of all combinations of brown (Sinden Hauser 3.8) or white (Horst U3) mushrooms, high $(95 \%)$ or low $(85 \%)$ relative humidity $(\mathrm{RH})$, and with or without soft rot bacteria $\left(\mathrm{W} 1 \mathrm{r} 3^{\mathrm{T}}\right)$ being added (24 replicates per treatment). An overnight culture of $\mathrm{W}_{1 \mathrm{r} 3^{\mathrm{T}}}$ in King's B Broth (King et al., 1954) was diluted with deionized water to $3.08 \times 10^{7}$ c.f.u. $\mathrm{ml}^{-1}$ and $100 \mathrm{ml}$ was applied to half of the pots as a drench. Both rooms were maintained at $90 \%$ RH until mushroom fruit bodies initially appeared on the casing surface after $12 \mathrm{~d}$. One chamber was then adjusted to $85 \%$ $\mathrm{RH}$ and the other to $95 \% \mathrm{RH}$. Mushrooms were harvested over 5 weeks and the weights and numbers which were healthy or diseased were recorded for each pot.

An in vitro experiment was performed to investigate the effect of RH on the development of disease symptoms. Sealed jars containing saturated solutions of salts were used as a simple method to provide atmospheres of known 
humidities (ASTM, 1963; Young, 1967). Kilner jars (1 lb) contained $30 \mathrm{~g}$ of the relevant salt to which $30 \mathrm{ml}$ sterile distilled water was added. White mushrooms (Horst U3), weighing approximately $8 \mathrm{~g}$, were then placed in weighing boats, the jars were sealed with a metal screw on the lids, with a central stoppered inoculation port, and equilibrated at $18{ }^{\circ} \mathrm{C}$ for $2 \mathrm{~h}$. The $\mathrm{RH}$ was then measured using a humidity probe (Vaisala) introduced through the inoculation port, connected to a data logger (SQ32; Grant Instruments). The mushrooms were inoculated by streaking strains $\mathrm{W} 1 \mathrm{r} 3^{\mathrm{T}}$, C1b4 and $\mathrm{H} 5$ onto the cap surfaces and then incubated for $4 \mathrm{~d}$ at $18^{\circ} \mathrm{C}$. The RH was checked every $24 \mathrm{~h}$. The salts used and the $\mathrm{RH}$ achieved (expected $\mathrm{RH}$ in parentheses) at $18^{\circ} \mathrm{C}$ were as follows: $\mathrm{NaCl}, 67.5$ (76); $\left(\mathrm{NH}_{4}\right)_{2} \mathrm{SO}_{4}, 71 \cdot 5(81) ; \mathrm{KCl}, 75(86) ;\left(\mathrm{NH}_{4}\right) \mathrm{H}_{2} \mathrm{PO}_{4}, 80$ (93); $\mathrm{K}_{2} \mathrm{SO}_{4}, 85(96 \cdot 5)$; sterile distilled $\mathrm{H}_{2} \mathrm{O}, 93(100)$.

\section{RESULTS}

Bacterial colonies of the three strains (W1r $3^{\mathrm{T}}, \mathrm{C} 1 \mathrm{~b} 4$ and $\mathrm{H} 5$ ) isolated from diseased mushrooms, grown on PAF after $48 \mathrm{~h}$ at $25^{\circ} \mathrm{C}$ were $3-4 \mathrm{~mm}$ in diameter, a translucent buff colour, circular, slightly convex, smooth and slightly mucoid. The texture was viscous. No pigment was produced initially but in older cultures, a buff, non-fluorescent pigment was seen. Strains were motile rods, $1.0-1.5 \times 1.8-2.5 \mu \mathrm{m}$, occurring singly or in pairs. All strains were oxidase- and catalase-positive, but indole- and Voges-Proskauernegative. Acid was produced from carbohydrates. No white line was produced between the test isolates and 'Pseudomonas reactans', indicating they were not $P$. tolaasii strains, and they did not grow well on PIA. Although a range of standard bacteriological tests were carried out with the isolate $\mathrm{W} 1 \mathrm{r} 3^{\mathrm{T}}$ (data not shown), a positive identification could not be made from these results and a more detailed study was performed.

Isolates $\mathrm{W} 1 \mathrm{r} 3^{\mathrm{T}}, \mathrm{C} 1 \mathrm{~b} 4$ and $\mathrm{H} 5$ all produced disease symptoms when applied to mushroom tissue blocks. $J$. lividum NCIMB 9230 and 9414 produced slight necrosis. However, the type strain of J. lividum, DSM

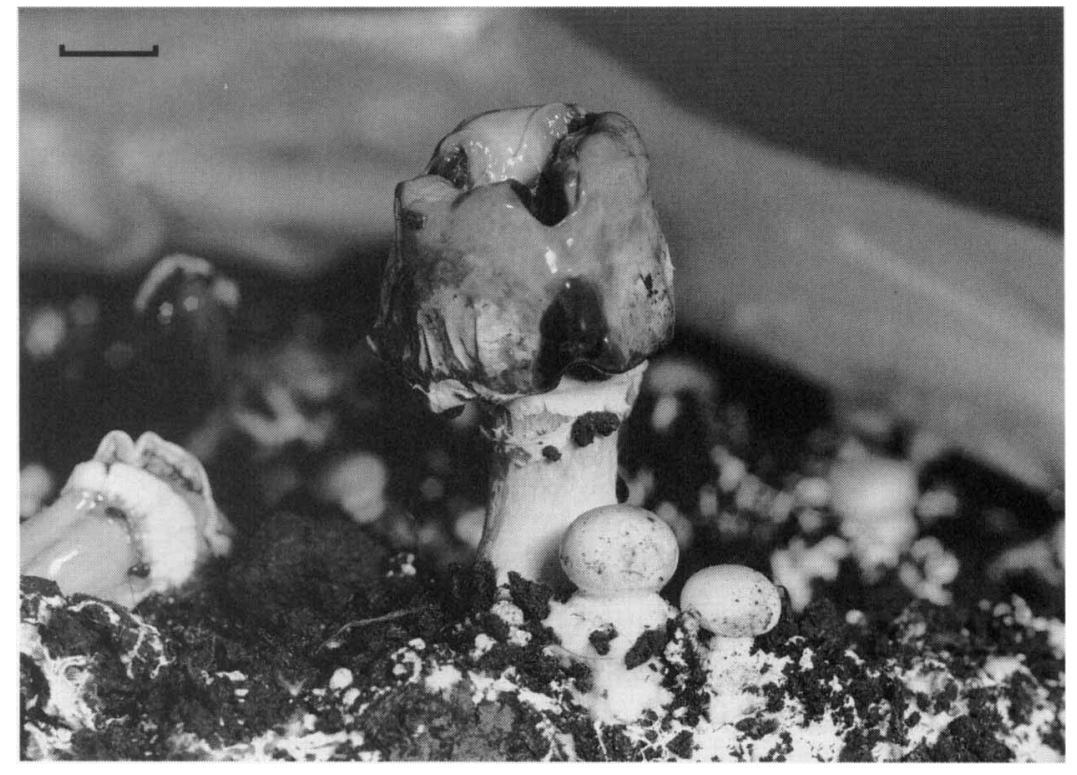

Fig. 1. Soft rot of $A$. bisporus (Horst U3) caused by isolate $\mathrm{W} 1 \mathrm{r}^{\top}$. Bar, $1 \mathrm{~cm}$.

Table 2. $16 \mathrm{~S}$ rDNA sequence similarity values of strain $\mathrm{W} 1 \mathrm{r} 3^{\top}$ and members of the genera Janthinobacterium, Herbaspirillum, Duganella, Oxalobacter and Telluria and Pseudomonas lemoignei

Strains: 1, W1r3 ${ }^{\mathrm{T}} ; 2$, Janthinobacterium lividum DSM $1522^{\mathrm{T}} ; 3$, Herbaspirillum seropedicae; 4, Duganella zoogloeoides; 5 , Pseudomonas lemoignei; 6, Oxalobacter formigenes; 7, Telluria mixta; 8, Telluria chitinolytica.

\begin{tabular}{|c|c|c|c|c|c|c|c|c|}
\hline Strain & 1 & 2 & 3 & 4 & 5 & 6 & 7 & 8 \\
\hline 1 & $100 \cdot 0$ & & & & & & & \\
\hline 2 & $99 \cdot 0$ & $100 \cdot 0$ & & & & & & \\
\hline 3 & $96 \cdot 4$ & 95.8 & $100 \cdot 0$ & & & & & \\
\hline 4 & $96 \cdot 1$ & $96 \cdot 5$ & 95.0 & $100 \cdot 0$ & & & & \\
\hline 5 & $94 \cdot 7$ & $94 \cdot 4$ & $95 \cdot 6$ & 93.8 & $100 \cdot 0$ & & & \\
\hline 6 & $93 \cdot 2$ & $93 \cdot 1$ & $95 \cdot 4$ & $92 \cdot 7$ & $93 \cdot 3$ & $100 \cdot 0$ & & \\
\hline 7 & 94.4 & $94 \cdot 5$ & $92 \cdot 4$ & $92 \cdot 9$ & $92 \cdot 3$ & $91 \cdot 1$ & $100 \cdot 0$ & \\
\hline 8 & $92 \cdot 9$ & 93.0 & 92.7 & 93.5 & $91 \cdot 4$ & $90 \cdot 6$ & $96 \cdot 2$ & $100 \cdot 0$ \\
\hline
\end{tabular}


Table 3. Fatty acid composition of members of the genus Janthinobacterium

Method 1 results in the release of ester-linked fatty acids; method 2 allows the detection of components which are presumptively amide-linked (methods were carried out at the different institutions given in the text). Numbers given are the percentages of each fatty acid compared to the total whole-cell fatty acids; TR, trace amount.

\begin{tabular}{|c|c|c|c|c|c|c|c|c|c|c|c|c|}
\hline \multirow[t]{3}{*}{ Fatty acid } & \multicolumn{6}{|c|}{ Mushroom isolate } & \multicolumn{6}{|c|}{ Janthinobacterium lividum } \\
\hline & \multicolumn{2}{|c|}{ H5 } & \multicolumn{2}{|c|}{ Clb4 } & \multicolumn{2}{|c|}{$W 13^{T}$} & \multicolumn{2}{|c|}{ DSM $1522^{\mathrm{T}}$} & \multicolumn{2}{|c|}{ NCIMB 9414} & \multicolumn{2}{|c|}{ NCIMB 9230} \\
\hline & 1 & 2 & 1 & 2 & 1 & 2 & 1 & 2 & 1 & 2 & 1 & 2 \\
\hline $3-\mathrm{OH} 10: 0$ & $2 \cdot 48$ & $3 \cdot 38$ & $2 \cdot 38$ & $3 \cdot 16$ & $2 \cdot 13$ & $3 \cdot 20$ & $2 \cdot 39$ & 4.03 & 1.69 & 3.57 & 2.64 & $4 \cdot 03$ \\
\hline $12: 0$ & $4 \cdot 65$ & 4.08 & 4.42 & $3 \cdot 70$ & 4.06 & 3.63 & 6.37 & $5 \cdot 20$ & 5.60 & $4 \cdot 88$ & $6 \cdot 16$ & $5 \cdot 11$ \\
\hline $2-\mathrm{OH} 12: 0$ & 1.02 & 0.81 & 1.09 & 0.94 & 0.85 & 0.87 & TR & $\mathrm{TR}$ & TR & $\mathrm{TR}$ & TR & $\mathrm{TR}$ \\
\hline $14: 0$ & 1.57 & 1.44 & 1.42 & 1.29 & 1.26 & 1.22 & $1 \cdot 14$ & 1.05 & 1.39 & 1.22 & $1 \cdot 15$ & 1.07 \\
\hline $15: 0$ & 0.73 & 0.71 & & & & & & & $1 \cdot 11$ & 1.06 & & 0.67 \\
\hline $16: 1 \omega 7 \mathrm{cis}$ & $24 \cdot 68$ & $24 \cdot 59$ & 26.09 & $24 \cdot 22$ & $23 \cdot 23$ & $22 \cdot 40$ & $41 \cdot 00$ & $38 \cdot 37$ & 39.93 & 37.61 & 43.09 & 40.72 \\
\hline $16: 0$ & 38.65 & 40.92 & $38 \cdot 20$ & $40 \cdot 35$ & 38.93 & 40.98 & $33 \cdot 02$ & $36 \cdot 11$ & $34 \cdot 24$ & $36 \cdot 17$ & $33 \cdot 95$ & $35 \cdot 33$ \\
\hline Unknown & & & & & & & & 0.72 & & & & \\
\hline Cyclo-17:0 & 23.89 & $22 \cdot 70$ & $24 \cdot 37$ & 23.68 & $26 \cdot 79$ & 26.07 & 13.42 & 11.07 & 13.29 & $12 \cdot 52$ & $10 \cdot 22$ & 9.82 \\
\hline $18: 1 \omega 7 c i s$ & 1.58 & $1 \cdot 38$ & 2.03 & 2.66 & 1.79 & 1.63 & $2 \cdot 67$ & 3.45 & 2.75 & 2.97 & 2.78 & $3 \cdot 24$ \\
\hline $\begin{array}{l}\% \text { of } 3-\mathrm{OH} \text { fatty acids which are } \\
\text { potentially amide-linked }\end{array}$ & & 26.67 & & $24 \cdot 82$ & & $33 \cdot 31$ & & $40 \cdot 83$ & & 52.73 & & 34.53 \\
\hline
\end{tabular}

Table 4. Fatty acid composition of members of the genus Herbaspirillum

Method 1 results in the release of ester-linked fatty acids; method 2 allows the detection of components which are presumptively amide-linked (methods were carried out at the different institutions given in the text). Numbers given are the percentages of each fatty acid compared to the total whole-cell fatty acids.

\begin{tabular}{|c|c|c|c|c|c|c|c|c|c|c|}
\hline \multirow[t]{2}{*}{ Fatty acid } & \multicolumn{2}{|c|}{$\begin{array}{l}\text { H. rubrisubalbicans } \\
\text { DSM } 9440^{\top}\end{array}$} & \multicolumn{2}{|c|}{$\begin{array}{c}\text { H. seropedicae } \\
\text { DSM } 6445^{\top}\end{array}$} & \multicolumn{2}{|c|}{$\begin{array}{l}\text { Herbaspirillum sp. } \\
\text { LMG } 2285\end{array}$} & \multicolumn{2}{|c|}{$\begin{array}{l}\text { Herbaspirillum sp. } \\
\text { LMG 5321 }\end{array}$} & \multicolumn{2}{|c|}{$\begin{array}{l}\text { Herbaspirillum sp. } \\
\text { LMG } 5523\end{array}$} \\
\hline & 1 & 2 & 1 & 2 & 1 & 2 & 1 & 2 & 1 & 2 \\
\hline $10: 0$ & & & & & 0.87 & & & & & 0.38 \\
\hline $3-\mathrm{OH} 10: 0$ & 1.39 & 1.45 & 0.85 & 1.05 & 0.78 & $1 \cdot 14$ & $0 \cdot 70$ & 0.80 & $1 \cdot 13$ & 1.23 \\
\hline $12: 0$ & $4 \cdot 33$ & $3 \cdot 36$ & & & 3.23 & $2 \cdot 98$ & $4 \cdot 35$ & $4 \cdot 18$ & 2.97 & $2 \cdot 92$ \\
\hline $2-\mathrm{OH} \quad 12: 0$ & & & 1.26 & $1 \cdot 19$ & & & & & & $0 \cdot 36$ \\
\hline $3-\mathrm{OH} 12: 0$ & $1 \cdot 33$ & $2 \cdot 93$ & 0.97 & $2 \cdot 72$ & 0.65 & 2.62 & 1.90 & 3.71 & 0.85 & 2.61 \\
\hline $14: 0$ & 0.96 & 0.83 & 3.74 & 3.56 & & & 0.71 & 0.67 & 0.55 & 0.51 \\
\hline $2-\mathrm{OH} 14: 0$ & 2.79 & $2 \cdot 15$ & $1 \cdot 12$ & 1.01 & $2 \cdot 16$ & $2 \cdot 19$ & $3 \cdot 16$ & 2.88 & 1.97 & 2.09 \\
\hline $16: 1 \omega 7 \mathrm{cis}$ & 35.01 & 32.58 & $37 \cdot 10$ & $36 \cdot 13$ & 34.04 & 33.72 & $41 \cdot 48$ & $39 \cdot 72$ & 32.01 & $34 \cdot 55$ \\
\hline $16: 1(?)$ & 4.65 & 3.86 & 2.01 & $2 \cdot 02$ & $2 \cdot 14$ & $2 \cdot 10$ & $2 \cdot 19$ & 1.94 & 2.67 & $3 \cdot 32$ \\
\hline Unknown & & & & & & & & & & 0.52 \\
\hline $16: 0$ & $22 \cdot 13$ & 23.66 & $22 \cdot 71$ & 23.06 & $20 \cdot 75$ & $22 \cdot 49$ & 18.66 & 19.89 & 18.34 & $21 \cdot 15$ \\
\hline Cyclo-17:0 & 6.22 & 5.92 & $4 \cdot 40$ & $4 \cdot 12$ & 7.09 & 6.34 & 3.24 & 2.96 & 3.04 & 3.29 \\
\hline Unknown & 1.09 & & 0.63 & 0.62 & & 0.62 & & & 0.47 & 0.52 \\
\hline $18: 1 \omega 7 \mathrm{cis}$ & $16 \cdot 73$ & $19 \cdot 44$ & 21.59 & $22 \cdot 32$ & $21 \cdot 18$ & $23 \cdot 19$ & $21 \cdot 19$ & $21 \cdot 22$ & 19.72 & $23 \cdot 28$ \\
\hline $18: 1(?)$ & $2 \cdot 43$ & $2 \cdot 72$ & $1 \cdot 11$ & $1 \cdot 14$ & 1.39 & 1.55 & 1.21 & 0.89 & 1.67 & 2.01 \\
\hline $18: 0$ & 0.93 & $1 \cdot 10$ & 0.97 & 1.06 & 0.89 & 1.07 & 1.20 & 1.14 & $1 \cdot 14$ & 1.27 \\
\hline $\begin{array}{l}\% \text { of 3-OH fatty acids which are potentially } \\
\text { amide-linked }\end{array}$ & & 37.97 & & 51.55 & & $62 \cdot 10$ & & $42 \cdot 19$ & & $48 \cdot 45$ \\
\hline
\end{tabular}

$1522^{\mathrm{T}}$, did not have any effect on the mushroom tissue after $48 \mathrm{~h}$. When isolates $\mathrm{W} 1 \mathrm{r} 3^{\mathrm{T}}$ or $\mathrm{C} 1 \mathrm{~b} 4$ were applied to beds of growing mushrooms, as a suspension in water, the disease symptoms could be reproduced and the bacteria re-isolated, thus satisfying Koch's postulates (Fig. 1). No soft rot symptoms were observed on control beds drenched with water, to which the test organisms had not been added, in the initial trial.

\section{Chemical and molecular analysis}

Fatty acid analysis of strains $\mathrm{W} 1 \mathrm{r} 3^{\mathrm{T}}, \mathrm{C} 1 \mathrm{~b} 4$ and $\mathrm{H} 5$ was initially carried out at CSL, Harpenden, and indicated that the fatty acid composition of these strains was similar to that of J. lividum. Based on this knowledge, it was possible to test the hypothesis that these strains were related to $J$. lividum, although members of this genus have not been reported to be pathogenic for mushrooms previously. Full 16S rDNA sequences $(1469 \mathrm{nt})$ were determined for isolate $\mathrm{W} 1 \mathrm{r} 3^{\mathrm{T}}$, a representative of the mushroom pathogen strains (Escherichia coli positions 29-1500). Analysis of the $16 \mathrm{~S}$ rDNA sequence of strain $\mathrm{W} 1 \mathrm{r} 3^{\mathrm{T}}$ showed that this organism was part of the $\beta$-subclass of the Proteobacteria (Woese, 1987). The 16S rDNA sequence of the type strain of $J$. lividum (DSM $1522^{\mathrm{T}}$ ) showed $99.0 \%$ (Table 2) sequence similarity to that of strain W1r3 ${ }^{\mathrm{T}}$ (EMBL no. Y08845), which is also consistent 
Table 5. Percentage fatty acid composition of members of the genera Janthinobacterium, Duganella, Herbaspirillum and Oxalobacter and Pseudomonas lemoignei

\begin{tabular}{|c|c|c|c|c|c|}
\hline Fatty acid & Duganella* & P. lemoignei ${ }^{\dagger}$ & Oxalobacter & Janthinobacterium & Herbaspirillum \\
\hline $10: 0$ & 2 & - & - & - & $0.0-0.9$ \\
\hline $3-\mathrm{OH} 10: 0$ & + & $3 \cdot 6$ & - & $3 \cdot 1-4 \cdot 0$ & $0 \cdot 8-1 \cdot 4$ \\
\hline $12: 0$ & 4 & $5 \cdot 3$ & $0-1$ & $3 \cdot 6-5 \cdot 2$ & $0 \cdot 0-4 \cdot 1$ \\
\hline 2-OH 12:0 & - & - & - & TR -0.94 & $0.0-1.1$ \\
\hline $3-\mathrm{OH} 12: 0$ & - & $5 \cdot 7$ & $4-6$ & - & $2 \cdot 6-3 \cdot 7$ \\
\hline $14: 0$ & 3 & $1 \cdot 3$ & $1-2$ & $1 \cdot 0-1 \cdot 4$ & $0 \cdot 0-3 \cdot 5$ \\
\hline 2-OH 14:0 & + & $4 \cdot 7$ & $8-10$ & - & $1 \cdot 0-2 \cdot 8$ \\
\hline $16: 1 \omega 7$ cis & $41 \S$ & $39 \cdot 3$ & $\mathrm{TR}-1 \S$ & $22 \cdot 4-40 \cdot 7$ & $32 \cdot 6-39 \cdot 7$ \\
\hline $16: 1(?)$ & & - & & & $1 \cdot 9-3 \cdot 8$ \\
\hline $16: 0$ & 38 & $12 \cdot 8$ & $28-33$ & $35 \cdot 3-40 \cdot 9$ & $19 \cdot 8-23 \cdot 7$ \\
\hline Cyclo-17:0 & - & 1.9 & $3-34$ & $9 \cdot 8-26 \cdot 7$ & $2 \cdot 9-5 \cdot 9$ \\
\hline $18: 1 \omega 7 c i s$ & $12 \S$ & $25 \cdot 5$ & $\mathrm{TR}-13 \S$ & $1 \cdot 38-3 \cdot 45$ & $19 \cdot 4-23 \cdot 2$ \\
\hline 18:1 (?) & & & & & $0.8-2 \cdot 7$ \\
\hline 18:0 & & - & TR-5 & - & \\
\hline Cyclo-19:0 & & - & $14-38$ & - & \\
\hline
\end{tabular}

TR, Trace amount.

* Data from Hiraishi et al. (1992).

$\dagger$ Data from Mergaert et al. (1996).

$\ddagger$ Data from Allison et al. (1985); includes both sub-groups.

$\S$ Hiraishi et al. (1992) and Allison et al. (1985) do not distinguish which isomers of $16: 1$ and 18:1 were present.

with the placement of $J$. lividum in this phyletic group in earlier reports based on DNA-RNA hybridization data (De Ley et al., 1978). Although DNA-RNA hybridization data have indicated an evolutionary relationship between members of the genera Janthinobacterium and Herbaspirillum (Baldani et al., 1996), the 16S rDNA sequence data showed that the organisms having the greatest degree of sequence similarity to the two Janthinobacterium species were members of the genera Herbaspirillum, Oxalobacter and Duganella and $P$. lemoignei (similarity values within the cluster $>95 \%$ ). The species $T$. mixta and $T$. chitinolytica were specifically associated with this phyletic group, but showed lower similarity values $(<95 \%)$. Members of the genera Ralstonia and Burkholderia were the next closest, but distinct, phyletic group, showing less than $92 \%$ sequence similarity (data not shown). Having established that all these organisms belonged to the same phyletic group, a chemotaxonomic study was undertaken to establish to what degree these various genera were justified. Fatty acid analysis of the organism, together with respiratory lipoquinone analysis was particularly useful due to the application of this method to members of the genera Oxalobacter (Allison et al., 1985) and Duganella (Hiraishi et al., 1992, 1997), together with data for various strains of $P$. lemoignei (Mergaert et al., 1996). The results obtained for the fatty acid composition of the Janthinobacterium and Herbaspirillum species used in this study (Tables 3 and 4) indicated that a clear separation could be made between the genus Janthinobacterium and the other organisms for which data are already available (Table 5).

Analysis of the respiratory lipoquinone content of the mushroom pathogen and members of the genera Janthinobacterium and Herbaspirillum indicated that only ubiquinones were present and that the major component was Q-8 in all strains tested.

The polar lipid compositions of the mushroom pathogens and several strains of $J$. lividum were determined to test their assignment to the same genus. The polar lipids were essentially identical, comprising mainly phosphatidyl ethanolamine, phosphatidyl glycerol and diphosphatidyl glycerol (Fig. 2).

In view of the high degree of similarity at the $16 \mathrm{~S}$ rDNA sequence and chemical levels, all further studies on the physiology of the mushroom pathogens were, therefore, restricted to a comparison with strains of the species $J$. lividum. The biochemical properties of the mushroom pathogen and several strains of J. lividum showed that two groups could easily be distinguished on the basis of the API 20NE, API 50CH and BIOLOG data (Tables 6,7 and 8). In summary, strains of the mushroom pathogen were rather less reactive than strains of J. lividum tested. On the basis of these findings, using representative strains of the two groups, it was tested whether DNA-DNA hybridization would also support the placement of the two groups into different species, within the genus Janthinobacterium. DNA-DNA hybridization between J. lividum DSM 


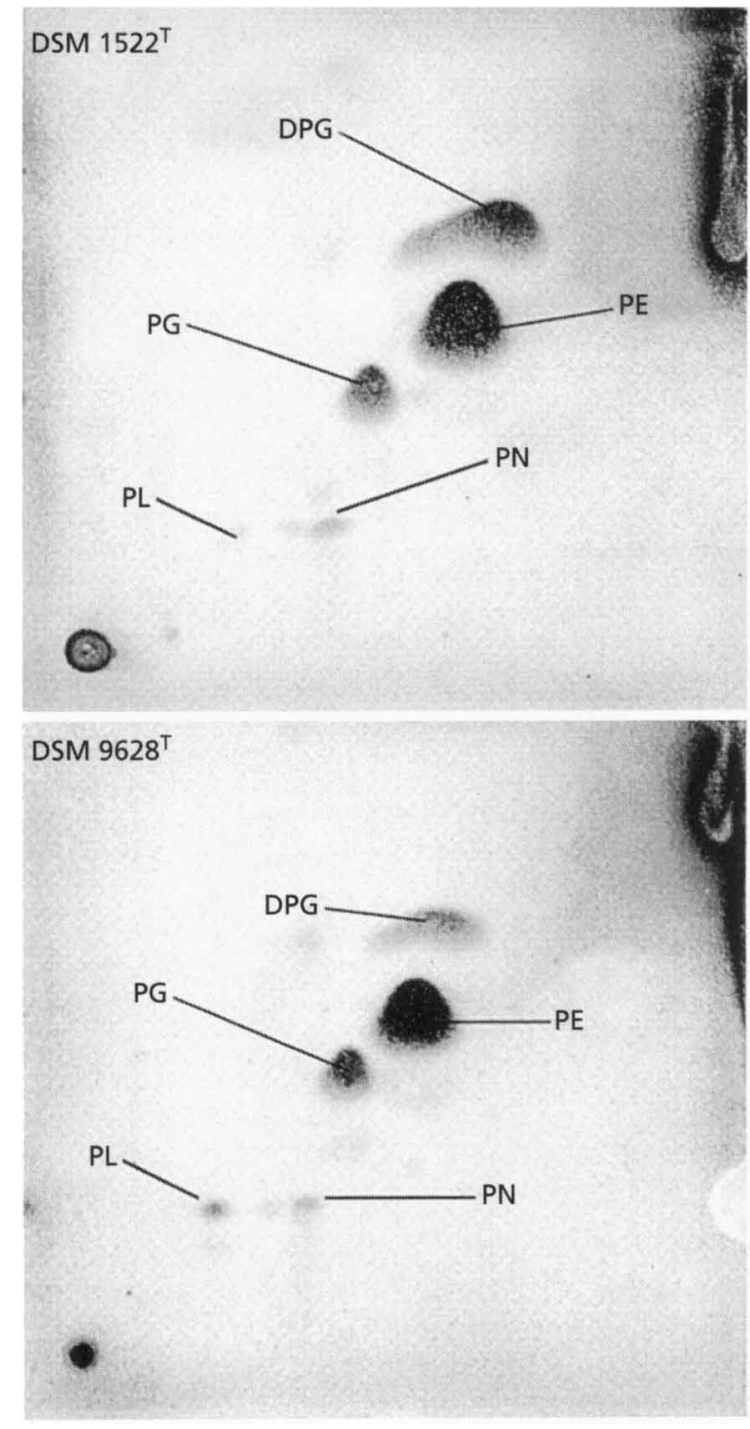

Fig. 2. Two-dimensional TLC of the polar lipids of J. lividum DSM $1522^{\top}$ and $J$. agaricidamnosum $\mathrm{W} 1 \mathrm{r}^{\top}$ (=DSM $9628^{\top}$ ). For details, see Methods. PG, Phosphatidyl glycerol; PE, phosphatidyl ethanolamine; DPG, diphosphatidyl glycerol; PL, phospholipid (not further characterized); PN, aminophospholipid (not further characterized).

$1522^{\mathrm{T}}$ and strain $\mathrm{W} 1 \mathrm{r} 3^{\mathrm{T}}$ gave a value of $35 \%$ which is well below the value generally considered to identify isolates as the same species (Johnson, 1984).

The $\mathrm{G}+\mathrm{C}$ content of the DNA was determined as $64 \cdot 2$ $\mathrm{mol} \%\left(T_{\mathrm{m}}\right.$ method) for $\mathrm{W} 1 \mathrm{r} 3^{\mathrm{T}}$, which is within the range given for the genus Janthinobacterium (61-67 $\mathrm{mol} \%$ ), which is currently represented by a single species, J. lividum (Sneath, 1984).

The resistance of $\mathrm{W} 1 \mathrm{r} 3^{\mathrm{T}}, \mathrm{C} 1 \mathrm{~b} 4, \mathrm{H} 5$, NCIMB 9230, NCIMB 9414 and DSM $1522^{\mathrm{T}}$ to a range of antibiotics was compared. All isolates were resistant to penicillin $\mathrm{G}(10 \mu \mathrm{g}$ disc) and vancomycin $(30 \mu \mathrm{g}$ disc), but showed no resistance to erythromycin ( $15 \mu \mathrm{g}$ disc), streptomycin $(10 \mu \mathrm{g}$ disc $)$, tetracycline $(30 \mu \mathrm{g}$ disc $)$ or nalidixic acid (30 $\mu \mathrm{g}$ disc).

Many of the results obtained in this study are characteristic for J. lividum but the isolates obtained in this study do not produce the purple pigment usually associated with this species. This purple pigment, violacein, is produced from tryptophan and can be synthesized by J.lividum, Chromobacterium violaceum, Iodobacter fluviatile and some members of the genus Pseudoalteromonas. However, it is possible to isolate and culture $J$. lividum and $C$. violaceum strains in a non-pigmented state (Logan \& Moss, 1992; Shivaji et al., 1991; Sivendra et al., 1975). Often pigmented and non-pigmented colony forms were seen in the same culture of the strains obtained from NCIMB and sometimes the pigment was lost altogether for one or two subcultures. This is possibly an example of intraclonal polymorphism as encountered in fluorescent pseudomonads and other bacteria described by Rainey et al. (1992b, 1993). However, pigment was never seen in any of the isolates from mushrooms.

\section{Host tests}

Mushroom crop experiment. At $85 \% \mathrm{RH}$, the brown mushroom strains appeared to be affected less by the disease than the white strains. However, $95 \%$ RH had more of an effect on the disease on the brown strains than on the white strains, making them more susceptible to soft rot at the higher humidity. The rather high percentage of mushrooms affected without having bacteria added was probably due to contamination during picking, watering or cross-contamination by flies. The percentages of diseased mushrooms produced for each treatment are given in Table 9. Infected mushrooms were too degraded to weigh.

It is normal mushroom-growing practice to keep the RH in cropping houses at $90 \%$ (Hermans, 1988). However, W1 $3^{\mathrm{T}}$ was isolated from a farm where the disease was causing a problem at that humidity. By reducing the $\mathrm{RH}$ in a cropping house to below $85 \%$ by careful control of ventilation and watering, a loss in total yield may be experienced, but the loss of mushrooms to this disease may be restricted, in the absence of any additional chemical controls. This method is already used for controlling outbreaks of brown blotch disease, caused by the bacterium $P$. tolaasii (Fletcher et al., 1989).

Laboratory humidity tests. The use of saturated salt solutions to create an atmosphere of known $\mathrm{RH}$ was partially successful. It was possible to equilibrate $\mathrm{RH}$ in sealed jars containing harvested mushrooms; however, the RH was lower than expected for each respective saturated salt solution. This was probably due to the nature of mushroom tissue, being absorbent and containing more than $90 \%(\mathrm{w} / \mathrm{w})$ water. However, a general trend showed no disease symptoms on W1 $3^{\mathrm{T}}$-inoculated mushrooms below $71.5 \% \mathrm{RH}$. 
Table 6. Differential characteristics of species of the genus Janthinobacterium based on respiratory activity mediated using BIOLOG GN plates

Tests negative for all strains were: $\alpha$-cyclodextrin, glycogen, $N$-acetyl-D-glucosamine, adonitol, D-arabitol, cellobiose, i-erythritol, $\alpha$-D-lactose, D-melibiose, methyl $\beta$-D-glucoside, monomethylsuccinate, cis-aconitic acid, citric acid, D-galactonic acid lactone, D-galacturonic acid, D-gluconic acid, D-glucosaminic acid, $\alpha$-hydrobutyric acid, $\gamma$-hydrobutyric acid, p-hydroxyphenylacetic acid, itaconic acid, quinic acid, D-saccharic acid, sebacic acid, glucuronamide, L-histidine, hydroxyl-L-proline, L-leucine, L-ornithine, L-phenylalanine, L-pyroglutamic acid, DL-carnitine, $\gamma$-aminobutyric acid, uridine, thymidine, phenylethylamine, putrescine, 2 -amino-ethanol and 2,3-butanediol. Tests positive for all strains were: $\alpha$-D-glucose, sucrose, methylpyruvate, formic acid, $\beta$-hydrobutyric acid, bromosuccinic acid, alaninamide, L-alanyl-glycine, glycyl-L-aspartic acid, glycyl-L-glutamic acid, DL-glycerol phosphate, glucose 1-phosphate and glucose 6-phosphate. v, Variable within strains.

\begin{tabular}{|c|c|c|}
\hline Test & J. lividum & J. agaricidamnosum \\
\hline Gentiobiose & - & $\mathrm{v}$ \\
\hline Lactulose & - & $\mathrm{v}$ \\
\hline d-Trehalose & - & + \\
\hline Turanose & - & $\mathrm{v}$ \\
\hline D-Glucuronic acid & - & $\mathrm{v}$ \\
\hline$m$-Inositol & - & $\mathrm{v}$ \\
\hline Urocanic acid & - & $\mathrm{v}$ \\
\hline Dextrin & + & - \\
\hline$N$-Acetyl-D-galactosamine & + & - \\
\hline D-Fucose & + & $\mathrm{v}$ \\
\hline Maltose & + & - \\
\hline D-Mannose & + & - \\
\hline D-Sorbitol & + & $\mathrm{v}$ \\
\hline Xylitol & + & - \\
\hline DL-Lactic acid & + & - \\
\hline Propionic acid & + & $\mathrm{v}$ \\
\hline Succinic acid & + & - \\
\hline Succinamic acid & + & - \\
\hline D-Alanine & + & - \\
\hline L-Alanine & + & - \\
\hline L-Asparagine & + & - \\
\hline L-Aspartic acid & + & - \\
\hline L-Glutamic acid & + & - \\
\hline L-Proline & + & - \\
\hline Inosine & + & - \\
\hline Tween 40 & $\mathrm{v}$ & + \\
\hline Tween 80 & $\mathrm{v}$ & + \\
\hline L-Arabinose & $\mathrm{v}$ & - \\
\hline L-Fucose & $\mathrm{v}$ & - \\
\hline D-Galactose & $\mathrm{v}$ & - \\
\hline D-Mannitol & $\mathrm{v}$ & - \\
\hline D-Psicose & $\mathrm{v}$ & - \\
\hline D-Raffinose & $\mathrm{v}$ & - \\
\hline L-Rhamnose & $\mathrm{v}$ & - \\
\hline Acetic acid & $\mathrm{v}$ & $\mathrm{v}$ \\
\hline$p$-Hydroxyphenylacetic acid & $\mathrm{v}$ & - \\
\hline$\alpha$-Ketobutyric acid & $\mathrm{v}$ & + \\
\hline$\alpha$-Ketoglutaric acid & $\mathrm{v}$ & - \\
\hline$\alpha$-Ketovaleric acid & $\mathrm{v}$ & + \\
\hline Malonic acid & $\mathrm{v}$ & $\mathrm{v}$ \\
\hline D-Serine & $\mathrm{v}$ & - \\
\hline L-Serine & $\mathrm{v}$ & - \\
\hline L-Threonine & $\mathrm{v}$ & - \\
\hline Glycerol & $\mathrm{v}$ & + \\
\hline
\end{tabular}


Table 7. Differential characteristics of species of the genus Janthinobacterium based on carbohydrate utilization in API $50 \mathrm{CH}$

Tests negative for all strains were: erythritol, L-xylose, adonitol, methyl $\beta$-xyloside, L-sorbose, dulcitol, methyl $\alpha$-D-mannoside, methyl $\alpha$-D-glucoside, amygdalin, aesculin, lactose, melibiose, melezitose, amidon, glycogen, D-turanose, D-tagatose, D-fucose, L-arabitol, gluconate and

5-ketogluconate. Tests positive for all strains were: glycerol, ribose, D-glucose, D-fructose, D-mannose, inositol, mannitol, saccharose and D-arabitol. v, Variable within strains.

\begin{tabular}{|lcc|}
\hline Test & J. lividum & J. agaricidamnosum \\
\hline Trehalose & - & + \\
$\beta$-Gentiobiose & - & + \\
D-Arabinose & + & - \\
L-Arabinose & + & - \\
D-Xylose & + & - \\
Galactose & + & - \\
Sorbitol & + & - \\
Arbutin & + & - \\
Salicin & + & - \\
Cellobiose & + & - \\
Maltose & + & - \\
Xylitol & + & - \\
D-Lyxose & + & - \\
L-Fucose & + & - \\
2-Ketogluconate & + & - \\
Rhamnose & $\mathrm{v}$ & - \\
$N$-Acetylglucosamine & $\mathrm{v}$ & - \\
Inulin & $\mathrm{v}$ & - \\
D-Raffinose & $\mathrm{v}$ & - \\
\hline
\end{tabular}

Table 8. Differential characteristics of species of the genus Janthinobacterium based on API 20NE tests

Tests negative for all strains were: production of gas from nitrate, production of indole from tryptophan, fermentation of glucose, presence of arginine dihydrolase, presence of urease, $\beta$-galactosidase activity, assimilation of glucose, gelatin hydrolysis and assimilation of gluconate. Tests positive for all strains were: assimilation of glucose, assimilation of malate, assimilation of mannose and assimilation of mannitol. $\mathrm{v}$, Variable within strains.

\begin{tabular}{|lcc|}
\hline Test & J. lividum & J. agaricidamnosum \\
\hline Nitrate reduction & + & - \\
Aesculin hydrolysis & + & - \\
Assimilation of: & & - \\
$\quad$ Arabinose & + & - \\
Maltose & + & $\mathrm{V}$ \\
Citrate & + & - \\
Phenylacetate & + & - \\
N-Acetylglucosamine & $\mathrm{v}$ & - \\
Caprate & $\mathrm{v}$ & - \\
Adipate & $\mathrm{v}$ & \\
\hline
\end{tabular}

Slight pitting and blotching occurred at $80 \% \mathrm{RH}$. At $85 \% \mathrm{RH}$, the mushrooms showed the first typical soft rot symptoms and extensive rotting occurred at $95 \%$ $\mathrm{RH}$.

\section{DISCUSSION}

The causal organism of this soft rot disease of $A$. bisporus is an aerobic Gram-negative rod which has a high degree of $16 \mathrm{~S}$ rDNA sequence similarity to members of the genus Janthinobacterium. It appears to be most active under very moist conditions and thus may have been introduced to mushroom farms through the water supply or casing peat as J. lividum is known to be found in soil and water (Moss et al., 1978; Moss \& Ryall, 1981). Strains H5, W1r3 ${ }^{\mathrm{T}}$ and C1 b4 and the three strains of $J$. lividum, including the type strain, were qualitatively identical in their chemical composition, with the exception of a 15:0 fatty acid present as a minor component in strains H5, NCIMB 9414 and 9230 only. However, there were biochemical differences between the type strain and two additional strains of $J$. lividum and the strains $\mathrm{Clb} 4, \mathrm{H} 5$ and W1r $3^{\mathrm{T}}$. Based on these data, it was concluded that strains $\mathrm{Clb} 4, \mathrm{H} 5$ and $\mathrm{W} 1 \mathrm{r} 3^{\mathrm{T}}$ should be placed in the genus Janthinobacterium, but as a separate species, a conclusion supported by the DNA-DNA hybridization data. Despite the fact that there is a high degree of $16 \mathrm{~S}$ rDNA sequence similarity $(>95 \%)$ to members of the genera Herbaspirillum, Oxalobacter and Duganella and P. lemoignei, these taxa are distinguishable on the basis of their fatty acid patterns from members of the genus Janthinobacterium. In particular, all organisms examined in this study and that of Mergaert et al. (1996) contained 16:0, 16:1 $\omega 7 c$ (cyclo-17:0) and $18: 1 \omega 7 c$ as the major fatty acids. Cyclopropane 17:0 fatty acids are synthesized from the corresponding 16:1 fatty acid and may be considered to be equivalent in the taxonomic evaluation. All organisms contained hydroxy fatty acids. However, in members of the genus Janthinobacterium, only 3-OH 10:0 and 2-OH 12:0 were synthesized, whereas in members of the genus Herbaspirillum and $P$. lemoignei, the major hydroxy fatty acids present were 3-OH 10:0, 3-OH 12:0 and 2-OH 14:0. Duganella zoogloeoides has been shown to synthesize only $3-\mathrm{OH}$ 10:0 and 2-OH 14:0, whereas Oxalobacter formigenes produces 3-OH 12:0 and 2-OH 14:0. Examination of the distribution of ester- and (presumptive) amidelinked 3-OH fatty acids indicated that in members of the genus Herbaspirillum the 3-OH 10:0 and 2-OH 14:0 fatty acids were ester-linked, whereas the $3-\mathrm{OH}$ 12:0 fatty acid was ester- and (presumptively) amidelinked. In contrast, the 3-OH 10:0 fatty acid of members of the genus Janthinobacterium were esterand (presumptively) amide-linked, and the 2-OH 12:0 fatty acids were ester-linked. Data on the distribution of ester- and amide-linked fatty acids from the other organisms is lacking in the literature. An interesting feature is that the use of differential hydrolysis of the fatty acids adds another dimension to the use of fatty 
Table 9. Effect of RH in cropping house and mushroom spawn strain on expression of $\mathrm{W} 1 \mathrm{r} 3^{\top}$ soft rot disease symptoms

\begin{tabular}{|lccc|}
\hline Mushroom strain & RH (\%) & + W1r T* $^{\text {* }}$ & Control $^{*}$ \\
\hline Brown (Sinden Hauser 3.8) & 95 & $66 \cdot 26$ & $33 \cdot 21$ \\
White (Horst U3) & 85 & $23 \cdot 21$ & $1 \cdot 79$ \\
& 95 & $54 \cdot 61$ & $29 \cdot 49$ \\
\hline
\end{tabular}

* Percentage diseased mushrooms by number; 24 replicated; standard error of differences 3.95.

acid analysis in prokaryotes. The fatty acid composition of the phyletic group defined by the genera Burkholderia and Ralstonia is also different, there being significant amounts of $2-\mathrm{OH} 16: 0$ and $3-\mathrm{OH}$ 14:0 fatty acids. In addition, some species may also contain 2-OH 16:0, 2-OH 16:1, 2-OH 18:1 and 3-OH 16:0, the latter being amide-linked in the polar lipid fraction (Cox \& Wilkinson, 1989; Galbraith \& Wilkinson, 1991; Oyaizu \& Komagata, 1983; Yabuuchi et al., 1992, 1995; Stead, 1992), which clearly differentiates the Burkholderia-Ralstonia phyletic group from the Janthinobacterium-DuganellaOxalobacter-Herbaspirillum phyletic group. On the basis of the fatty acid data available, we consider that members of the genus Janthinobacterium can be distinguished from members of the genera Duganella, Oxalobacter and Herbaspirillum, which we conclude supports the distinct taxonomic rank of these genera. This is consistent with the placement of the organisms within the $\beta$-subclass of the Proteobacteria and is also in accordance with the finding of Q-8 in members of the genera Duganella (Hiraishi et al., 1992, 1997) and Telluria (Bowman et al., 1993). There are other differences between the various other taxa, which would indicate that they also are deserving of placement in different genera. Members of the genus Oxalobacter are obligate anaerobes (Allison et al., 1985), whereas members of the genus Herbaspirillum utilize a much wider range of substrates than members of the genus Janthinobacterium (Baldani et al., 1996; B. J. Tindall, unpublished results). If one were to reduce this phyletic group to a single genus, for which the name Janthinobacterium has priority, the genus would comprise a physiologically and chemically heterogeneous assemblage. Although closer study of members of the genus Herbaspirillum and P. lemoignei should be undertaken, it is quite clear that each of the genera compared in the present study may be unambiguously distinguished from one another and we advocate retaining these genera. These results also indicate that the use of similarity values alone to define taxa as previously proposed should be questioned (Devereux et al., 1990; Fry et al., 1991), since it amounts to an overweighting of the 16S rDNA data, rather than a balanced integration with other data of evolutionary relevance. The arbitrary assignment of an organism to a higher taxonomic rank (i.e. genus) should be supported by appropriate evidence. The problem has been discussed previously (Tindall, 1994). Although such guidelines (i.e. sequence similarity values) may be useful, they should be treated with caution and altered according to the state of our knowledge. In the present work, we have presented chemical evidence which clearly separates the genus Janthinobacterium from other genera with which it shares between 95 and $96.6 \%$ sequence similarity.

The results presented here may be taken as supporting the hypothesis that the mushroom pathogenic strains show a high degree of similarity and, therefore, constitute a monophyletic group, for which placement in the same species would be appropriate. They also share similarities with members of the genus Janthinobacterium (Tables 3, 6, 7 and 8) and members of this genus, in turn, share similarities with members of the genera Herbaspirillum, Duganella and Oxalobacter (Table 2). Despite the high degree of similarity, a number of phenotypic differences were noted between the strains of the species $J$. lividum tested and strains $\mathrm{C} 1 \mathrm{~b} 4, \mathrm{H} 5$ and $\mathrm{W} 1 \mathrm{r} 3^{\mathrm{T}}$. These differences may be used to distinguish between members of the species $J$. lividum and strains $\mathrm{Clb} 4, \mathrm{H} 5$ and $\mathrm{W} 1 \mathrm{r} 3^{\mathrm{T}}$, which may be placed in a new species within the genus Janthinobacterium, for which we propose the name Janthinobacterium agaricidamnosum sp. nov.

The current definition of the genus Janthinobacterium, based on the descriptions of De Ley et al. (1978) and Sneath (1984), would exclude the new species from this genus. It is, therefore, necessary to emend the description of this genus.

\section{Janthinobacterium (De Ley et al., 1978) emend.}

Data of significance in defining members of the genus Janthinobacterium are given in Tables 3, 6, 7 and 8, based on fatty acid patterns and the API 20NE, API $50 \mathrm{CH}$ and the BIOLOG test systems, which allow the placement of a strain in the genus Janthinobacterium as emended in this work. The fatty acid pattern also serves to differentiate this genus from members of other genera showing a high $(>95 \%)$ degree of sequence similarity (Table 5 ). Q-8 is the major respiratory lipoquinone, as in all members of the $\beta$ subclass of the Proteobacteria studied to date (Collins 
\& Jones, 1981; Yokota et al., 1992; B. J. Tindall, unpublished results). The major phospholipids are phosphatidyl ethanolamine, phosphatidyl glycerol and diphosphatidyl glycerol. The fatty acid composition comprises 3-OH 10:0, 12:0, 2-OH 12:0, 14:0, 16:0, $16: 1 \omega 7 c$, cyclo- $17: 0$ and $18: 1 \omega 7 c$. A significant fraction of the $3-\mathrm{OH} 10: 0$ fatty acid is (presumptively) amide-linked.

\section{Description of Janthinobacterium agaricidamnosum sp. nov.}

Janthinobacterium agaricidamnosum (a'ga'ri.ci.dam. nosum. L. masc. n. agaricus mushroom; L. adj. damnosum damaging; agaricidamnosum damaging the mushroom).

Rods $1.0-1.5 \times 1.8-2.5 \mu \mathrm{m}$. Cells occur singly or in pairs. No resting stage is known. Cells stain Gramnegative with lipid inclusions. Motile. Produce low convex, round, beige colonies on solid media. Maximum growth temperature, $30^{\circ} \mathrm{C}$; minimum, $2{ }^{\circ} \mathrm{C}$. No growth below $\mathrm{pH} 5$ or in media containing $2.9 \% \mathrm{NaCl}$. Acid is produced from glucose. Oxidase-positive, catalase-positive, indole-negative and VogesProskauer-negative. Nitrate and nitrite are not reduced. Utilizes citrate and ammonium ions as sole carbon and nitrogen sources for growth. The organism does not produce a purple pigment. Resistant to penicillin $\mathrm{G}(10 \mu \mathrm{g}$ disc) and vancomycin $(30 \mu \mathrm{g}$ disc) . $16 \mathrm{~S}$ rDNA sequence analysis of strain $\mathrm{W} 1 \mathrm{r} 3^{\mathrm{T}}$ shows $99 \%$ similarity to the type strain of Janthinobacterium lividum (DSM $1522^{\mathrm{T}}$ ). The $\mathrm{G}+\mathrm{C}$ content is $64 \cdot 2$ mol \%. Chemical composition is as described for the genus. Tests which allow the rapid differentiation of $J$. lividum and $J$. agaricidamnosum are summarized in Tables 6,7 and 8 . The type strain $\left(\mathrm{W} 1 \mathrm{r}^{\mathrm{T}}\right)$ was isolated as the cause of a soft rot disease of the cultivated mushroom $A$. bisporus. Strain $\mathrm{W} 1 \mathrm{r} 3^{\mathrm{T}}$ has been deposited in culture collections as DSM $9628^{\mathrm{T}}$ and NCPPB $3945^{\mathrm{T}}$.

\section{ACKNOWLEDGEMENTS}

The authors are grateful to David Stead, Jenny Sellwood and Andy Aspin, ADAS Central Science Laboratory, Sand Hutton, York, UK, for performing whole-cell fatty acid analyses and for their opinion on the identification of the bacteria. We thank Jean-Marc Olivier, INRA, Bordeaux, France, for the donation of the isolate designated $\mathrm{H} 5$, Richard Gaze, Horticulture Research International, for first bringing this soft rot disease to our attention, and Jutta Burghardt and F. A. Rainey for technical assistance with the DNA-DNA hybridization and 16S rDNA sequence work. This work was carried out under MAFF contract no. HH0124JMU.

\section{REFERENCES}

Allison, M. J., Dawson, K. A., Mayberry, W. R. \& Foss, J. G. (1985). Oxalobacter formigenes gen. nov., sp. nov.: oxalate degrading anaerobes that inhabit the gastrointestinal tract. Arch Microbiol 141, 1-7.

ASTM (1963). Recommended practice for maintaining constant relative humidity by means of aqueous solutions. ASTM (Am Soc Test Mater), E104-E151.

Baldani, J. l., Pot, B., Kirchhof, G. \& 8 other authors (1996). Emended description of Herbaspirillum: inclusion of [Pseudomonas] rubrisubalbicans, a mild plant pathogen, as Herbaspirillum rubrisubalbicans comb. nov.; and classification of a group of clinical isolates (EF Group 1) as Herbaspirillum species 3. Int J Syst Bacteriol 46, 802-810.

Bowman, J.P., Sly, L. I., Hayward, A. C., Spiegel, Y. \& Stackebrandt, E. (1993). Telluria mixta (Pseudomonas mixta Bowman, Sly \& Hayward 1988) gen. nov., comb. nov., and Telluria chitinolytica sp. nov., soil-dwelling organisms which actively degrade polysaccharides. Int $J$ Syst Bacteriol 43, $120-124$

Cashion, P., Holder-Franklin, M. A., McCully, J. \& Franklin, M. (1977). A rapid method for the base ratio determination of bacterial DNA. Anal Biochem 81, 461-466.

Collins, M. D. \& Jones, D. (1981). Distribution of isoprenoid quinone structural types in bacteria and their taxonomic implications. Microbiol Rev 45, 316-354.

Cox, A. D. \& Wilkinson, S. G. (1989). Polar lipids and fatty acids of Pseudomonas cepacia. Biochim Biophys Acta 1001, 60-67.

De Ley, J., Cattoir, H. \& Reynaerts, A. (1970). The quantitative measurement of DNA hybridization from renaturation rates. Eur J Biochem 12, 133-142.

De Ley, J., Segers, P. \& Gillis, M. (1978). Intra and intergeneric similarities of Chromobacterium and Janthinobacterium ribosomal ribonucleic acid cistrons. Int $J$ Syst Bacteriol 28,154-168.

Devereux, R., He, S.-H., Doyle, C. L., Orkland, S., Stahl, D. A., LeGall, J. \& Whitman, W. B. (1990). Diversity and origin of Desulfovibrio species: phylogenetic definition of a family. $J$ Bacteriol 172, 3609-3619.

Escara, J. F. \& Hutton, J.R. (1980). Thermal stability and renaturation of DNA in dimethylsulphoxide solutions: acceleration of renaturation rate. Biopolymers 19, 1315-1327.

Fletcher, J. T., White, P. F. \& Gaze, R. H. (1989). Mushrooms: Pests and Disease Control, 2 nd edn, 174 pp. Andover: Intercept. Fry, N. K., Warwick, S., Saunders, N. A. \& Embley, T. M. (1991). The use of $16 \mathrm{~S}$ rRNA analyses to investigate the phylogeny of the family Legionellaceae. J Gen Microbiol 137, 1215-1222.

Galbraith, L. \& Wilkinson, S. G. (1991). Polar lipids and fatty acids of Pseudomonas caryophylli, Pseudomonas gladioli and Pseudomonas pickettii. J Gen Microbiol 137, 197-202.

Gandy, D. E. (1968). A technique for screening bacteria causing Brown blotch of cultivated mushrooms. Rep Glasshouse Crops Res Inst (1967), 150-154.

Gerhardt, P., Murray, R. G. E., Costilow, R. N., Nester, E. W., Wood, W. A., Krieg, N. R. \& Phillips, G. B. (1981). Manual of Methods for General Microbiology. Washington, DC: American Society for Microbiology.

Hermans, C. (1988). Climate and cultivation techniques. In The Cultivation of Mushrooms, pp. 213-248. Edited by L. J. L. D. van Griensven. Sussex, UK: Darlington Mushroom Laboratories.

Hiraishi, A., Shin, Y. K., Sugiyama, J. \& Komagata, K. (1992). Isoprenoid quinones and fatty acids of Zoogloea. Antonie Leeuwenhoek 61, 231-236. 
Hiraishi, A., Shin, Y. K. \& Sugiyama, J. (1997). Proposal to reclassify Zoogloea ramigera IAM 12670 (P. R. Dugan 115) as Duganella zoogloeoides gen. nov., sp. nov. Int J Syst Bacteriol 47, 1249-1252.

Inglis, P. W., Burden, J. L. \& Peberdy, J. F. (1996). Evidence for the association of the enteric bacterium Ewingella americana with internal stipe necrosis of Agaricus bisporus. Microbiology 142, 3253-3260.

Jahnke, K. D. (1992). BASIC computer program for evaluation of spectroscopic DNA renaturation data from Gilford system 2600 spectrophotometer on a PC/XT/AT type personal computer. J Microbiol Methods 15, 61-73.

Johnson, J. L. (1984). Nucleic acids in bacterial classification. In Bergey's Manual of Systematic Bacteriology, vol. 1, pp. 8-11. Edited by N. R. Kreig \& J. G. Holt. Baltimore: Williams \& Wilkins.

King, E. O., Ward, M. K. \& Raney, D. E. (1954). Two simple media for the demonstration of pyocyanin and fluorescein. J Lab Clin Med 44, 301-307.

Lelliott, R. A. \& Stead, D. E. (1987). Methods for the Diagnosis of Bacterial Diseases of Plants. Oxford: Blackwell Scientific Publications.

Lincoln, S. P., Fermor, T. R., Stead, D. E. \& Sellwood, J. E. (1991). Bacterial soft rot of Agaricus bitorquis. Plant Pathol 40, 136-144.

Logan, N. A. \& Moss, M. O. (1992). Identification of Chromobacterium, Janthinobacterium, and Iodobacter species. In Identification Methods in Applied and Environmental Microbiology, Technical Series vol. 29, 183-192. Edited by R. G. Board, D. Jones \& F. A. Skinner. Bedford, UK: Society for Applied Bacteriology.

Ludwig, W. \& Strunk, O. (1996). ARB: a software environment for sequence data. http://www.mikro.biologie.tu-muenchen.de/ pub/ARB/documentation/arb.ps. Technische Universität München, Munich, Germany.

Maidak, B. L., Olsen, G. J., Larsen, N., Overbeek, R., McCaughey, M. J. \& Woese, C. R. (1997). The RDP (Ribosomal Database Project). Nucleic Acids Res 25, 109-111.

Marmur, J. \& Doty, P. (1962). Determination of the base composition of deoxyribonucleic acid from its thermal denaturation temperature. $J$ Mol Biol 4, 109-118.

Mergaert, J., Schirmer, A., Hauben, L., Mau, M., Hoste, B., Kersters, K., Jendrossek, D. \& Swings, J. (1996). Isolation and identification of poly(3-hydroxyvalerate)-degrading strains of Pseudomonas lemoignei. Int J Syst Bacteriol 46, 769-773.

Mesbah, M., Premachandran, U. \& Whitman, W. (1989). Precise measurement of the $\mathrm{G}+\mathrm{C}$ content of deoxyribonucleic acid by high-performance liquid chromatography. Int J Syst Bacteriol 39, 159-167.

Moss, M. O. \& Ryall, C. (1981). The genus Chromobacterium. In The Prokaryotes, pp. 1355-1364. Edited by M. P. Starr, H. Stolp, H. G. Trüper, A. Balows \& H. G. Schlegel. Berlin: Springer.

Moss, M. O., Ryall, C. \& Logan, N. A. (1978). The classification and characterization of chromobacteria from a lowland river. $J$ Gen Microbiol 105, 11-21.

Moss, C. W., Dees, S. B. \& Guerrans, G. O. (1980). Gas chromatography of bacterial fatty acids with a fused silica capillary column. J Clin Microbiol 12, 127-130.

Neumann, B., Pospiech, A. \& Schairer, H. U. (1992). Rapid isolation of genomic DNA from Gram-negative bacteria. Trends Genet 8, 332-333.
Oyaizu, H. \& Komagata, K. (1983). Grouping of Pseudomonas species on the basis of cellular fatty acid composition and the quinone system with special reference to the existence of 3 hydroxy fatty acids. J Gen Appl Microbiol 29, 17-40.

Paine, S. G. (1919). Studies in bacteriosis. II. A brown blotch disease of cultivated mushrooms. Ann Appl Biol 5, 206-219.

Rainey, F. A. \& Stackebrandt, E. (1993). 16S rDNA analysis reveals phylogenetic diversity among the polysaccharolytic clostridia. FEMS Microbiol Lett 113, 125-128.

Rainey, F. A., Dorsch, M., Morgan, H. W. \& Stackebrandt, E. (1992a). 16S rDNA analysis of Spirochaeta thermophila: position and implications for the systematics of the order Spirochaetales. Syst Appl Microbiol 16, 224-226.

Rainey, P. B., Brodey, C. L. \& Johnstone, K. (1992b). Biology of Pseudomonas tolaasii, cause of Brown Blotch disease of the cultivated mushroom. Adv Plant Pathol 8, 95-117.

Rainey, P. B., Moxon, E. R. \& Thompson, I. P. (1993). Intraclonal polymorphism in bacteria. Adv Microb Ecol 13, 263-300.

Shivaji, S., Ray, M. K., Seshu Kumarg, G., Reddy, G. S. N., Saisree, L. \& Wynn-Williams, D. D. (1991). Identification of Janthinobacterium lividum from the soils of the island of Scotia Ridge and from Antarctic peninsula. Polar Biol 11, 267-271.

Sivendra, R., Lo, H. S. \& Lim, K. T. (1975). Identification of Chromobacterium violaceum: pigmented and non-pigmented strains. J Gen Microbiol 90, 21-31.

Sneath, P. H. A. (1984). Genus Janthinobacterium De Ley, Segers \& Gillis 1978, 164 AL . In Bergey's Manual of Systematic Bacteriology, vol. 1, pp. 376-377. Edited by N. R. Kreig \& J. G. Holt. Baltimore: Williams \& Wilkins.

Stead, D. E. (1992). Grouping of plant-pathogenic and some other Pseudomonas spp. by using cellular fatty acid profiles. Int $J$ Syst Bacteriol 42, 281-295.

Tamaoka, J. \& Komagata, K. (1984). Determination of DNA base composition by reversed-phase high-performance liquid chromatography. FEMS Microbiol Lett 25, 125-128.

Tindall, B. J. (1990a). A comparative study of the lipid composition of Halobacterium saccharovorum from various sources. Syst Appl Microbiol 13, 128-130.

Tindall, B. J. (1990b). Lipid composition of Halobacterium lacusprofundi. FEMS Microbiol Lett 66, 199-202.

Tindall, B. J. (1994). Chemical analysis of Archaea and Bacteria: a critical evaluation of its use in taxonomy and identification. In Bacterial Diversity and Systematics, FEMS Symposium No. 75. Edited by F. G. Priest, A. Ramos-Cormenzana \& B. J. Tindall. New York: Plenum.

Woese, C. R. (1987). Bacterial evolution. Microbiol Rev 51, 221-227.

Wong, W. C. \& Preece, T. F. (1979). Identification of Pseudomonas tolaasii: the white line in agar and mushroom tissue block rapid pitting test. $J$ Appl Bacteriol 47, 401-407.

Wong, W. C., Fletcher, J. T., Unsworth, B. A. \& Preece, T. F. (1982). A note on ginger blotch, a new disease of the cultivated mushroom Agaricus bisporus. J Appl Bacteriol 52, 43-48.

Yabuuchi, E., Kosako, Y., Oyaizu, H., Yano, I., Hotta, H., Hashimoto, Y., Ezaki, T. \& Arakawa, M. (1992). Proposal of Burkholderia gen. nov. and transfer of seven species of the genus Pseudomonas homology group II to the new genus, with the type species Burkholderia cepacia (Palleroni and Holmes 1981) comb. nov. Microbiol Immunol 36, 1251-1275.

Yabuuchi, E., Kosako, Y., Yano, I., Hotta, H. \& Nishiuchi, Y. (1995). 
Transfer of two Burkholderia and an Alcaligenes species to Ralstonia gen. nov.: proposal of Ralstonia pickettii (Ralston, Palleroni and Doudoroff 1973) comb. nov., Ralstonia solanacearum (Smith 1896) comb. nov. and Ralstonia eutropha (Davis 1969) comb. nov. Microbiol Immunol 39, 897-904.

Yokota, A., Akagawa-Matsushita, M., Hiraishi, A., Katayama, Y., Urakami, T. \& Yamasato, K. (1992). Distribution of quinone systems in micro-organisms: Gram-negative eubacteria. Bull Jpn Fed Cult Coll 8, 136-171.

Young, J. F. (1967). Humidity control in the laboratory using salt solutions - a review. J Appl Chem 17, 241-245.

Young, J. M. (1970). Drippy gill: a bacterial disease of mushrooms caused by Pseudomonas agarici n. sp. NZ J Agric Res 13, 977-990. 